\title{
Tracing carbon and nitrogen incorporation and pathways in the microbial community of a photic subtidal sand
}

\author{
Victor Evrard ${ }^{1,3, *}$, Perran L. M. Cook ${ }^{2,4}{ }^{\text {, Bart Veuger }}{ }^{1}$, Markus Huettel ${ }^{2,5}$, \\ Jack J. Middelburg ${ }^{1}$
}

\author{
${ }^{1}$ Netherlands Institute of Ecology, Center for Estuarine and Marine Ecology, PO Box 140, 4400 AC Yerseke, The Netherlands \\ ${ }^{2}$ Max Planck Institute for Marine Microbiology, Celsiusstrasse 1, Bremen 28359, Germany \\ ${ }^{3}$ Present address: Department of Oceanography, University of Hawai'i at Manoa, 1000 Pope Road, Honolulu, Hawai'i 96822, USA \\ ${ }^{4}$ Present address: Water Studies Centre, Monash University, Victoria 3800, Australia \\ ${ }^{5}$ Present address: Florida State University, Tallahassee, Florida 32306-4320, USA
}

\begin{abstract}
The pathways and fate of $\mathrm{C}$ and $\mathrm{N}$ in the microbial compartment of a coastal permeable sandy sediment in the photic zone were studied in a pulse-chase experiment. ${ }^{13} \mathrm{C}$-bicarbonate and ${ }^{15} \mathrm{~N}$-nitrate were added to the water column on top of 5 sediment cores incubated in 4 transparent and 1 opaque laboratory chambers. After $9 \mathrm{~h}$ of labelling in the light and dark, stable isotope incorporation by microphytobenthos (MPB) and bacteria was quantified over a period of $4 \mathrm{~d}$ through the analysis of phospholipid-derived fatty acids (PLFA) and hydrolysable amino acids (HAA). ${ }^{13} \mathrm{C}$ was fixed by $\mathrm{MPB}$, and more than $50 \%$ was directed to the production of extracellular polymeric substance (EPS). $\mathrm{MPB}{ }^{15} \mathrm{~N}$ incorporation was similar in the dark and in the light. Bacterial activity appeared to have 2 effects that depended on sediment depth: at the sediment surface, there was a steady increase of label in the bacterial PLFA, suggesting metabolism of label-containing EPS; in the subsurface layers, uniform enrichment started immediately after the labelling procedure, indicating continuous incorporation of inorganic $\mathrm{C}$ by chemoautotrophic bacteria (Cbac). This experiment demonstrates the efficient transfer of inorganic $\mathrm{C}$ and $\mathrm{N}$ to the benthic community through the activities of photo- and chemoautotrophic microorganisms, and the role of EPS as a carrier of energy to the benthic microbial food web.
\end{abstract}

KEY WORDS: Microphytobenthos - Cyanobacteria - EPS - PLFA - Biomarkers · Amino acids · Chemoautotrophy $\cdot$ Permeable sediment $\cdot{ }^{15} \mathrm{~N} \cdot{ }^{13} \mathrm{C} \cdot$ Stable isotopes $\cdot$ Nitrate

Resale or republication not permitted without written consent of the publisher

\section{INTRODUCTION}

Coastal sediments have traditionally been considered donor-controlled ecosystems in which supplied detritus of variable quality is mineralised. During the last 2 decades, there has been a growing awareness that primary production by microphytobenthos (MPB) can contribute significantly to organic C production (MacIntyre et al. 1996) and moderate sediment C flows in the coastal zone (Middelburg et al. 2000). This key role of MPB in coastal primary production and benthic $\mathrm{C}$ flows has been documented particularly in intertidal flats that receive abundant light during exposure (MacIntyre et al. 1996, Underwood \& Kromkamp 1999). Recently, Gattuso et al. (2006) suggested that net benthic primary production may take place on more than $33 \%$ of the global shelf area. This implies that the contribution of MPB to the global C cycle may have been underestimated until now.

Subtidal sediments in the photic zone typically show 3 major metabolic pathways: phototrophy, heterotrophy and chemoautotrophy. Phototrophy primarily concerns $\mathrm{CO}_{2}$ fixation by benthic microalgae (BMA) and cyanobacteria, the 2 major components of the MPB 
(Fig. 1). In the surface layer, MPB often represents the most important component in terms of biomass and turnover and modulates $\mathrm{C}$ and $\mathrm{N}$ transfer across the sediment-water interface (MacIntyre et al. 1996, Sundback et al. 1996). Although C fixation and N assimilation are often closely related to the buildup of biomass, a large part of the $\mathrm{C}$ fixed may be diverted to synthesis of extracellular polymeric substances (EPS) that can account for a large fraction of organic C present in the sediment (Smith \& Underwood 1998, Goto et al. 1999, Wieland et al. 2008). The second major pathway is heterotrophy: the utilisation of detritus, MPB, EPS and other organic substrates by heterotrophic bacteria (Hbac), meiofauna and macrofauna. Heterotrophic benthic organisms produce new biomass (secondary production) and govern mineralization of organic matter. The third metabolic pathway is chemoautotrophy: the fixation of $\mathrm{CO}_{2}$ using the energy released upon oxidation of reduced inorganic compounds. This topic has received limited attention in the literature, yet it may constitute a significant pathway close to redox boundaries (Kristensen \& Hansen 1995, Thomsen \& Kristensen 1997).

Although the biological importance of subtidal permeable sediments was recognized decades ago (Riedl et al. 1972), these systems remain poorly documented. In contrast to fine grained sediments, which are characterised by large stocks of organic matter, permeable sediments have long been wrongly considered as biogeochemically limited (Boudreau et al. 2001) because of their low pore water nutrient concentrations and low organic C contents. Nevertheless, recent studies have highlighted the biogeochemical importance of permeable sediments, where interfacial water flow strongly facilitates pore water and organic matter exchange between the sediment and the water

\begin{tabular}{|c|c|c|c|c|c|c|c|c|}
\hline \multicolumn{3}{|c|}{ Terminology } & Biological compartment & \multicolumn{5}{|c|}{ Biomass } \\
\hline & & & & \multicolumn{3}{|c|}{$\mathrm{C}$ and $\mathrm{N}$} & \multicolumn{2}{|c|}{ C only } \\
\hline \multirow{5}{*}{ 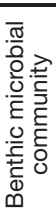 } & \multirow{5}{*}{$\begin{array}{l}\stackrel{m}{a} \\
\Sigma\end{array}$} & \multirow{3}{*}{ 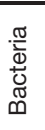 } & Heterotrophic bacteria (Hbac) & \multirow{8}{*}{ 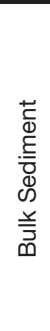 } & \multirow{7}{*}{ 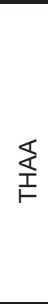 } & \multirow{3}{*}{$\frac{\pi}{4}$} & & 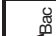 \\
\hline & & & Chemoautotrophic bacteria (Cbac) & & & & & 岀 \\
\hline & & & Cyanobacteria (Cy) & & & & \multirow{3}{*}{$\frac{\frac{\sigma}{\tau}}{\frac{\pi}{U}}$} & \multirow{3}{*}{ 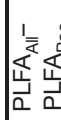 } \\
\hline & & \multirow{2}{*}{ 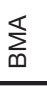 } & Diatoms & & & & & \\
\hline & & & Haptophytes & & & & & \\
\hline \multicolumn{4}{|r|}{ Meiofauna and microfauna } & & & & & \\
\hline \multicolumn{4}{|r|}{ Detritus } & & & & & \\
\hline \multicolumn{4}{|r|}{ EPS } & & & & & \\
\hline
\end{tabular}

Fig. 1. Schematic overview of benthic $\mathrm{C}$ and $\mathrm{N}$ pools, microbial community composition and corresponding proxies. BMA: benthic microalgae; Chl a: chlorophyll $a$; D-ala: D-alanine; EPS: extracellular polymeric substances; MPB: microphytobenthos; PLFA $_{\text {All }}$ : all phospholipid-derived fatty acids; PLFA $_{\mathrm{Bac}}$ : bacterial-specific phospholipid-derived fatty acids; THAA: total hydrolysable amino acids. Grey shading indicates negligible relative contribution for estimation of stable isotope transfer column, thus enhancing organic matter supply to the sands and remineralization (Huettel \& Gust 1992a,b, Huettel et al. 1996, Huettel \& Rusch 2000, Rusch \& Huettel 2000, Precht \& Huettel 2003). Advective pore water flow allows reactive compounds to be transported more efficiently into the sediment, making them available to the bacterial community attached to the sand grains (Rusch et al. 2001, Franke et al. 2006), thus conferring these sediments with important biocatalytic filter properties (Huettel et al. 2003, Ehrenhauss et al. 2004). The low $C$ content of sandy, permeable sediments is not a consequence of sediment inactivity but rather of high organic C turnover (Boudreau et al. 2001, Dauwe et al. 2001, de Beer et al. 2005), which in turn may have an important influence on the overall oceanic C cycle (Shum \& Sundby 1996).

Sandy sediments cover about $70 \%$ of the continental shelf (Emery 1968) and a substantial part of these sediments receive enough light to sustain primary production (Jahnke et al. 2000, Gattuso et al. 2006). Thus, these sands may contribute significantly to the shelf and global $\mathrm{C}$ cycles. Therefore, quantitative data on the flow of $\mathrm{C}$ within subtidal permeable sediments inhabited by MPB in which phototrophic, heterotrophic and chemoautotrophic pathways co-occur are of great interest, for example as input data for coastal and global models of $\mathrm{C}$ and nutrient cycles.

In the present study, we followed the fate of fixed C and assimilated $\mathrm{N}$ through the benthic microbial compartment after a deliberate tracer addition of ${ }^{13} \mathrm{C}$ bicarbonate and ${ }^{15} \mathrm{~N}$-nitrate to sediment cores. Through the use of stable isotopes and microbial biomarker techniques involving phospholipid-derived fatty acids (Middelburg et al. 2000, Boschker \& Middelburg 2002, Boschker et al. 2005) and hydrolysable amino acids (HAA), including the bacterial biomarker D-alanine (Veuger et al. 2005), we can follow the fate of $\mathrm{C}$ and $\mathrm{N}$ within the different microbial components. The objective was to determine the pathways and conversion rates of $\mathrm{C}$ and $\mathrm{N}$ contained in the biomass and exudates of autotrophic benthic organisms inhabiting subtidal photic permeable sands. Moreover, we assessed the relative contributions of the different metabolic pathways and the differential fate of $\mathrm{C}$ and $\mathrm{N}$.

\section{MATERIALS AND METHODS}

Study site. The research was carried out in List, on the Island of Sylt (Germany) in July 2004. The sampling site, the Hausstrand, was situated south of List Harbour close to a site studied earlier by de Beer et al. (2005). 
The area is exposed to the east and strongly influenced by wind-driven waves and north-south tidal currents parallel to the shore. Water depth at the sampling site ranged between 0.5 and $2.5 \mathrm{~m}$, depending on the tidal amplitude, and the salinity between 27.5 and 31 for spring and summer, respectively (Hedtkamp 2005). The sediment is composed of silicate sand with a median grain size of $350 \mu \mathrm{m}$ (M. Huettel unpubl. data), a porosity of 0.42 and an organic $\mathrm{C}$ content of $\sim 0.2 \%$ $\left(250 \mathrm{~g} \mathrm{C} \mathrm{m}^{-2}\right)$ (Evrard 2007).

Incubation experiment. Five transparent and 1 opaque acrylic cylinders $(19 \mathrm{~cm}$ inner diameter $\times 33 \mathrm{~cm}$ high) were used to sample a set of 6 sediment cores with their overlying water. At the time of sampling, the water depth was approximately $1.5 \mathrm{~m}$. The cores (approximately $15 \mathrm{~cm}$ of sediment and $18 \mathrm{~cm}$ of overlying seawater) were immediately transferred to the laboratory, where the cylinders were closed with acrylic lids. Each lid carried an electric motor that propelled a $15 \mathrm{~cm}$ diameter horizontal rotating disc that stirred the water column at $15 \mathrm{~cm}$ above the sediment-water interface. The motor maintained an electronically controlled angular velocity of $40 \mathrm{rpm}$, which generated a pressure gradient of $1.9 \mathrm{~Pa}\left(\sim 0.2 \mathrm{~Pa} \mathrm{~cm}^{-1}\right)$ between the circumference and the centre of the sediment surface. This pressure gradient corresponds to the gradient produced by slow bottom currents $\left(\sim 10 \mathrm{~cm} \mathrm{~s}^{-1}\right)$ interacting with sediment ripple topography $(15 \mathrm{~mm}$ ripple amplitude) as were typical for the study site during our investigations. The pressure gradient forces water through the upper layer of the permeable sand, entering the sediment at the ripple troughs and emerging at the ripple crests. In the chamber, the water enters the sediment near the chamber wall and emerges from the centre of the core. These laboratory-generated advective flows through the permeable beds are a prerequisite for ecologically relevant incubations. The functioning and deployment of these chambers has been described in detail by Huettel \& Gust (1992b), Huettel et al. (1996) and Janssen et al. (2005a,b)

The set of chambers was immersed in a $200 \mathrm{ltank}$, filled with seawater from the field site, maintained under in situ temperature $\left(20^{\circ} \mathrm{C}\right)$ and constantly aerated. Each chamber's upper lid with stirrer was elevated $\sim 1 \mathrm{~cm}$ above the chamber's edge, allowing circulation of aerated water within the whole system. Water circulation was enhanced by a submersible water pump placed at the bottom of the trough. The system was left to settle for $24 \mathrm{~h}$ before the experiment started. On the following day, one of the transparent cores was immediately sampled to provide background values $(T=0)$. The other cores were hermetically closed and received a pulse of $850 \mathrm{mmol}$ $\mathrm{NaH}^{13} \mathrm{CO}_{3}$, equivalent to a $10 \%{ }^{13} \mathrm{C}$-labelling of the dissolved inorganic C (DIC) pool $\left(1950 \mu \mathrm{mol} \mathrm{l}^{-1}\right)$, and
$170 \mathrm{mmol} \mathrm{Na}{ }^{15} \mathrm{NO}_{3}$, equivalent to $95 \%$ labelling of the dissolved inorganic $\mathrm{N}$ (DIN) pool $\left(<5 \mu \mathrm{mol} \mathrm{l}^{-1}\right)$ (Hedtkamp 2005). The 4 transparent cores were illuminated by artificial light, providing an irradiance of $185 \mu \mathrm{mol}$ quanta $\mathrm{m}^{-2} \mathrm{~s}^{-1}$ at the sediment surface, which corresponded to measured in situ light intensities. Net primary production was estimated on the first day from the difference in oxygen increase in the light and oxygen decrease in the dark. Oxygen concentrations were measured using Winkler titrations (Grasshoff et al. 1999) of samples taken in the light $(\mathrm{n}=3)$ and in the dark $(\mathrm{n}=1)$ at $t=0,2.1,3.4$ and $4.9 \mathrm{~h}$, starting from the beginning of the illumination period. After $9 \mathrm{~h}$, the light was switched off and the water column of the 5 cores was flushed twice to remove the added tracers and replaced with seawater from the study site. Care was taken to avoid disrupting the sediment surface. A 9:15 h light:dark cycle was kept during the $4 \mathrm{~d}$ of the experiment. The cores were always submerged in the trough to allow aeration and mixing of the water within the whole system, and were closed only during flux measurements.

At each time step after the labelling period $(\mathrm{T}=1,2,3$ and $4 \mathrm{~d}$ ), just before the period of illumination, one core was removed from the trough and its sediment sampled as follows: 4 subsamples were taken from the core using 4 small core liners $\left(3.56 \mathrm{~cm}\right.$ diameter, $\left.\sim 10 \mathrm{~cm}^{2}\right)$. For organic $\mathrm{C}$ and $\mathrm{N}$, phospholipid-derived fatty acids (PLFA) and total hydrolysable amino acids (THAA) content and analysis, 3 cores were sliced into $0-1,1-2$, $2-3,3-4,4-5$ and $5-10 \mathrm{~cm}$, and layers of the same depth were pooled to limit the heterogeneity inherent to microbial communities in sandy sediments as much as possible. The remaining subsample core was sliced at $0-2,2-4,4-6,6-8,8-10$ and $10-20 \mathrm{~mm}$ for pigment distribution analysis. All sediment samples were freeze-dried and stored in a freezer until analysis.

Analyses and data handling. Small fractions of the sediment samples were ground in agate mortars to obtain a fine and homogeneous sediment powder. Organic $\mathrm{C}$ (remaining after acidification) and $\mathrm{N}$ contents and their isotopic compositions $\left({ }^{13} \mathrm{C}\right.$ and $\left.{ }^{15} \mathrm{~N}\right)$ were measured from those fractions using an elemental analyser (Carlo Erba/Fisons/Interscience) coupled via a ConFlo II interface to an isotope ratio mass spectrometer (EA-IRMS, Finnigan Delta S).

PLFA for all layers down to $5 \mathrm{~cm}$ were extracted from approximately $6 \mathrm{~g}$ of dry sediment per layer following the methods of Boschker et al. (1999) and Middelburg et al. (2000), and their concentrations were determined by gas chromatography with flame ionization detection (GC-FID, Carlo Erba HRGC mega 2 GC). PLFA stable $\mathrm{C}$ isotopic composition was determined by gaschromatography-combustion-isotope ratio mass spectrometry (GC-c-IRMS, Hewlett Packard 6890 GC 
coupled via a Thermo combustion interface III to a Thermo Delta Plus isotope ratio mass spectrometer). Bacterial and MPB C contents in the sediment were estimated from the PLFA concentrations. Bacterial biomass (Bac, mmol $\mathrm{C} \mathrm{m}^{-2}$ ) was calculated from bacterial PLFA $\left(\mathrm{PLFA}_{\mathrm{Bac}}\right)$ as $\mathrm{Bac}=\mathrm{PLFA}_{\mathrm{Bac}} / a$, where $a$ is the average PLFA concentration in bacteria $(0.073 \mathrm{mmol}$ of C PLFA per mmol of C bacteria for aerobic sediments; Brinch-Iversen \& King 1990, Moodley et al. 2000). PLFA $_{\text {Bac }}$ was estimated from the bacteria-specific PLFA

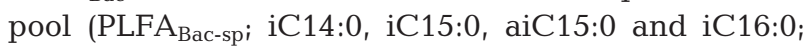
specific of both heterotrophic and chemoautotrophic bacteria) as $\mathrm{PLFA}_{\mathrm{Bac}}=\Sigma \mathrm{PLFA}_{\mathrm{Bac}-\mathrm{sp}} / b$, where $b$ is the average fraction-specific bacterial PLFA $(0.14 \mathrm{mmol}$ of $C$ bacterial-specific PLFA per mmol of carbon bacterial PLFA; Moodley et al. 2000). MPB biomass (expressed in mmol $\mathrm{C} \mathrm{m}^{-2}$ ) was calculated from the difference between total PLFA $\left(\right.$ PLFA $_{\text {All }}$ ) and the PLFA ${ }_{\mathrm{Bac}}$ as MPB $=\left(\Sigma \mathrm{PLFA}_{\mathrm{All}}-\mathrm{PLFA}_{\mathrm{Bac}}\right) / C$, where $c$ is the average PLFA concentration in MPB (0.053 mmol of C PLFA per mmol MPB). We calculated $c$ as the weighted average PLFA concentration in a mix of different phytoplankton monocultures similar to the MPB composition (Dijkman \& Kromkamp 2006, N. A. Dijkman pers. comm.).

HAA concentrations and their ${ }^{13} \mathrm{C}$ and ${ }^{15} \mathrm{~N}$ enrichment were measured for the $0-1 \mathrm{~cm}$ layer by GCC-IRMS (Veuger et al. 2005, 2006). ${ }^{13} \mathrm{C}$ and ${ }^{15} \mathrm{~N}$ incorporation into the bacterial-specific amino acid D-alanine (D-Ala) is expressed relative to that of total $\mathrm{D}+\mathrm{L}$-alanine (L-Ala is a stable constituent of the HAA pool of all organisms), as the ${ }^{13} \mathrm{C}$ or ${ }^{15} \mathrm{~N}$ D/L-Ala incorporation ratio $\left({ }^{13} \mathrm{C}\right.$ or ${ }^{15} \mathrm{~N}$ incorporation in $\mathrm{D}$ $\mathrm{Ala} /{ }^{13} \mathrm{C}$ or ${ }^{15} \mathrm{~N}$ incorporation in $\mathrm{D}+\mathrm{L}$-Ala) to obtain an
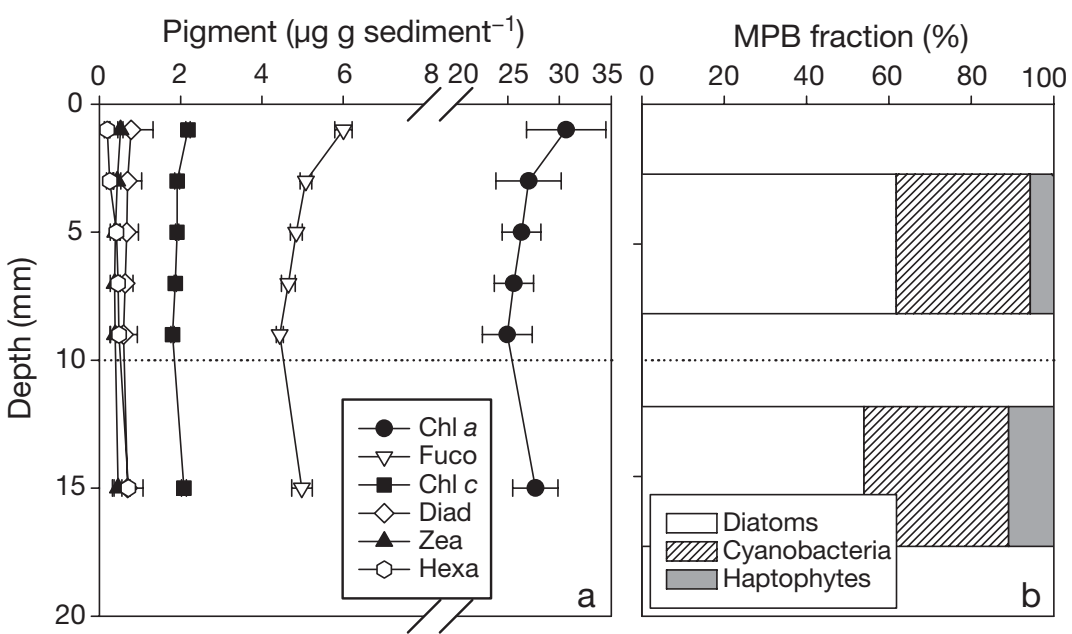

Fig. 2. Pigment and microphytobenthos (MPB) composition of the sediment. (a) Depth profiles of chlorophyll a (Chl a), fucoxanthin (Fuco), chlorophyll $c$ $(\mathrm{Chl} c)$, diadinoxanthin (Diad), zeaxanthin (Zea) and 19-hexanoyloxyfucoxanthin (Hexa). (b) MPB composition calculated by CHEMTAX for the 0-10 and $10-20 \mathrm{~mm}$ sediment layers estimate of the bacterial contribution to total ${ }^{13} \mathrm{C}$ and ${ }^{15} \mathrm{~N}$ incorporation.

Stable isotope data were expressed in delta notation $\left(\delta^{13} \mathrm{C}\right.$ and $\delta^{15} \mathrm{~N}$, in \%o) relative to Vienna Pee Dee Belemnite (VPDB) for $\mathrm{C}$ and air for N. Following Maddi et al. (2006), we used the enrichment $\left(\delta^{\mathrm{E}}\right.$ notation, in $\%$ ) as a measure of label enrichment:

$$
\mathrm{X} \delta^{\mathrm{E}}=\left[\left(\delta \mathrm{X}_{\mathrm{s}}+1000\right) /\left(\delta \mathrm{X}_{\mathrm{b}}+1000\right)-1\right] \times 1000
$$

where $\mathrm{X}$ is ${ }^{13} \mathrm{C}$ or ${ }^{15} \mathrm{~N}$, b is background (natural abundance) and $\mathrm{s}$ is sample (enriched). Atomic excess was defined as $\mathrm{E}=\mathrm{F}_{\mathrm{s}}-\mathrm{F}_{\mathrm{b}}$, the difference between the stable isotope fraction of the sample and that of the background. $F=R /(R+1)$, where $R$ is the stable isotope ratio calculated from the $\delta$-value. $R=(\delta X / 1000+1) \times$ $\mathrm{R}_{\mathrm{VPDB} / \mathrm{Air}}$, with $\mathrm{R}_{\mathrm{VPDB}}=0.0111797$ and $\mathrm{R}_{\text {Air }}=0.0036765$. The incorporation, $\mathrm{I}=\mathrm{E} \times \mathrm{B}$, also defined as the total uptake of label by Middelburg et al. (2000), was expressed in mmol $\mathrm{X} \mathrm{m}^{-2}$, where $\mathrm{B}$ is the biomass (organic C, N, C-PLFA or C-and N-amino acid).

Pigment samples were analysed by reverse-phase HPLC (Barranguet et al. 1998), and data expressed in $\mu \mathrm{g}$ g sediment $^{-1}$. Relative fractions of MPB taxa were estimated using the CHEMTAX program (Mackey et al. 1996).

\section{RESULTS}

\section{MPB composition, biomass and production}

With 4800 and $11600 \mathrm{mmol} \mathrm{C} \mathrm{m}^{-2}$ for the top 2 and $5 \mathrm{~cm}$ of sediment, respectively, organic C content was relatively high $(\sim 0.21 \%$ of dry weight for the $0-1 \mathrm{~cm}$ layer). The vertical concentration profiles of pigments over the first $20 \mathrm{~mm}$ of sediment suggest a homogeneous distribution of MPB within the photic zone (i.e. the upper few $\mathrm{mm}$ ) and below (Fig. 2). Average chlorophyll a (chl a) contents were $82 \pm 10$ and $793 \pm$ $70 \mathrm{mg} \mathrm{m}^{-2}$ in the top 2 and upper $20 \mathrm{~mm}$, respectively, and did not significantly change over the course of the experiment. Pigment data relevant for MPB group identification are shown in Fig. 2a. Chlorophyll $b(\mathrm{chl} b)$ and lutein were not detected, indicating the absence of green algae. Chl a concentrations appeared to be correlated with fucoxanthin and, together with the presence of chlorophyll $C$ $(\mathrm{chl} c)$ and diadinoxanthin, suggested that MPB was dominated by diatoms. This was confirmed by the output of the CHEMTAX analysis (Fig. 2b), indicating that 
diatoms represented approximately 60 and $55 \%$ of the MPB for the depth layers 0-10 and 10-20 mm, respectively. Cyanobacteria accounted for approximately $30 \%$ of the MPB biomass and haptophytes (phytoplankton) contributed the remaining $\sim 10 \%$. Considering their small contribution and to simplify further discussion, we neglected the haptophytes and only diatoms and cyanobacteria were taken into account with proportions of 66 and $33 \%$, respectively. Finally, primary production based on oxygen evolution was $1.68 \mathrm{mmol} \mathrm{m}^{-2} \mathrm{~h}^{-1}$.

\section{Label transfer}

${ }^{13} \mathrm{C}$ and ${ }^{15} \mathrm{~N}$ enrichment in bulk sediment was initially rapid and slightly decreased after Day 2 (Fig. 3a,b). Enrichment mainly occurred at the sediment surface with maximal $\delta^{\mathrm{E}}$ values of 73 and $1220 \%$ for ${ }^{13} \mathrm{C}$ and ${ }^{15} \mathrm{~N}$, respectively, reached on Day 2 . The deeper layers were much less enriched and, for the $1-2$ cm layer ${ }^{13} \mathrm{C}$ and ${ }^{15} \mathrm{~N}$ enrichment maxima were reached on Day 3 , which may be ascribed to the burial of labelled particulate organic matter due to pore water advection or bioturbation. The comparison of $\mathrm{C}$ and $\mathrm{N}$ uptake in light and dark cores on Day 4 showed a striking difference in label uptake between $\mathrm{C}$ and $\mathrm{N}$ : in contrast to $\mathrm{C}, \mathrm{N}$ uptake also occurred in the dark. ${ }^{15} \mathrm{~N}$ dark enrichment reached $75 \%$ of the value measured for the light incubation.

PLFA ${ }^{13} \mathrm{C}$ enrichment was significant and rapid from Day 1 on (Fig. 3c,d). Within the $0-1$ cm layer (Fig. 3c), the diatom-specific biomarker $\mathrm{C} 20: 5 \omega 3$ was the most abundant (data not shown) and the relatively strong enrichment reached a maximum of $67 \%$ on Day 2 . The presence of $\mathrm{C} 18: 3 \omega 3$ and $\mathrm{C} 18: 3 \omega 4$ in the absence of green algae can be attributed to cyanobacteria. $\mathrm{C} 18: 3 \omega 3$ and $\mathrm{C} 18: 3 \omega 4$ enrichments were highest on Day 2 with $\delta^{\mathrm{E}}$ values of 225 and $159 \%$, respectively. Cyanobacteria-related PLFAs of the underlying layer were far less enriched than in the $0-1 \mathrm{~cm}$ layer but increased slightly over time, suggesting gradual burial (Fig. 3d). However, the diatom-specific PLFA showed very low enrichment in the subsurface layers. MPB PLFA enrichment in the dark was negligible both at the sediment surface and deeper in the sediment (Fig. 3c,d). Bacterial-specific PLFAs at the sediment surface showed less ${ }^{13} \mathrm{C}$ enrichment (only iC15:0 and aiC15:0 were represented with a maximal $\delta^{\mathrm{E}}$ of 12 and $8 \%$, respectively) than MPB and followed roughly the same enrichment pattern as the algal PLFAs, although they reached their maximum on Day 3 (Fig. 3c). The enrichment of bacterial PLFA for the 1-2 cm layer showed the opposite trend, with a maximum enrichment on Day 1 followed by a decrease over time (Fig. 3d). Enrichment in the dark was very low but noticeable, particularly in the 1-2 cm layer where the $\delta^{\mathrm{E}}$ value for the bacterial PLFA aiC15:0 was the highest of all bacterial-specific PLFAs, suggesting the presence of chemoautotrophic bacteria. In addition, from Day 3 on, a white biofilm was visible at the sediment surface in the centre of the cores where outflow of reduced pore water created an interface between anoxic sediment and the oxic water column. Underneath the white bio-
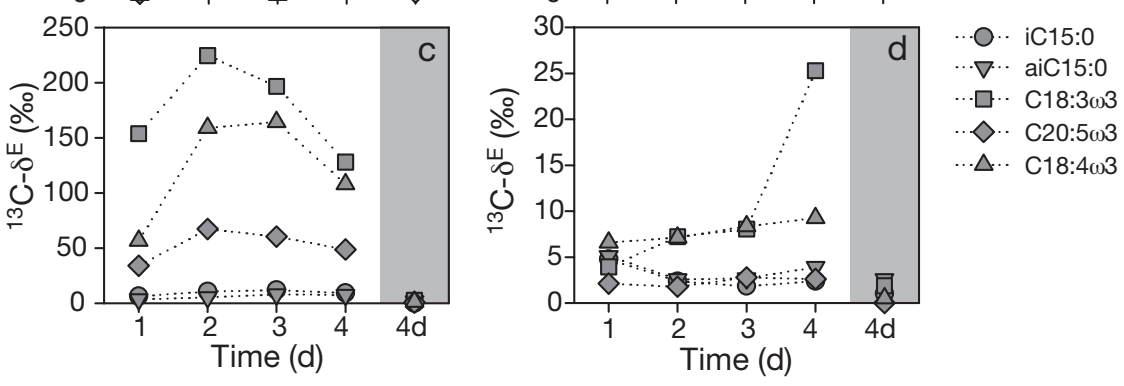

Fig. 3. (a) ${ }^{13} \mathrm{C}$ and (b) ${ }^{15} \mathrm{~N}$ enrichment over time in bulk sediment for the different layers. ${ }^{13} \mathrm{C}$ enrichment in bacterial-specific PLFAs (iC15:0, aC15:0), diatom-specific

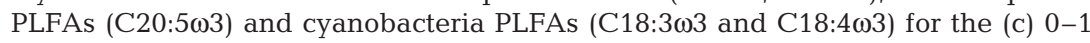
and (d) 1-2 cm sediment layers. Shaded area shows values for dark incubation on Day $4(4 \mathrm{~d})$

\section{$\mathrm{C}$ and $\mathrm{N}$ assimilation}

\begin{abstract}
film was a $\sim 15 \mathrm{~mm}$ diameter black spot at the sediment surface, characteristic of reduced compounds, which contrasted with the rest of the brown sediment surface.

-O- $0-1 \mathrm{~cm}$ $-\square-2-3 \mathrm{~cm}$ $\checkmark-4 \mathrm{~cm}$ $\triangle-4-5 \mathrm{~cm}$
\end{abstract} $\square: C$ 15:0 $18: 3 \omega 3$ $20: 5 \omega 3$

Bulk sediment incorporation of ${ }^{13} \mathrm{C}$ and ${ }^{15} \mathrm{~N}$ showed similar dynamics (Fig. 4a,b). The incorporation between 5 and $10 \mathrm{~cm}$ depth was not significant (data not shown). While the enrichments presented in Fig. 3a,b clearly reflect the increase in stable isotope ratios due to label uptake, Fig. 4a,b shows the actual amounts of label uptake that were measured in the sediments over the $4 \mathrm{~d}$ course of the experiment. Total organic $\mathrm{C}$ and $\mathrm{N}$ concentrations did 

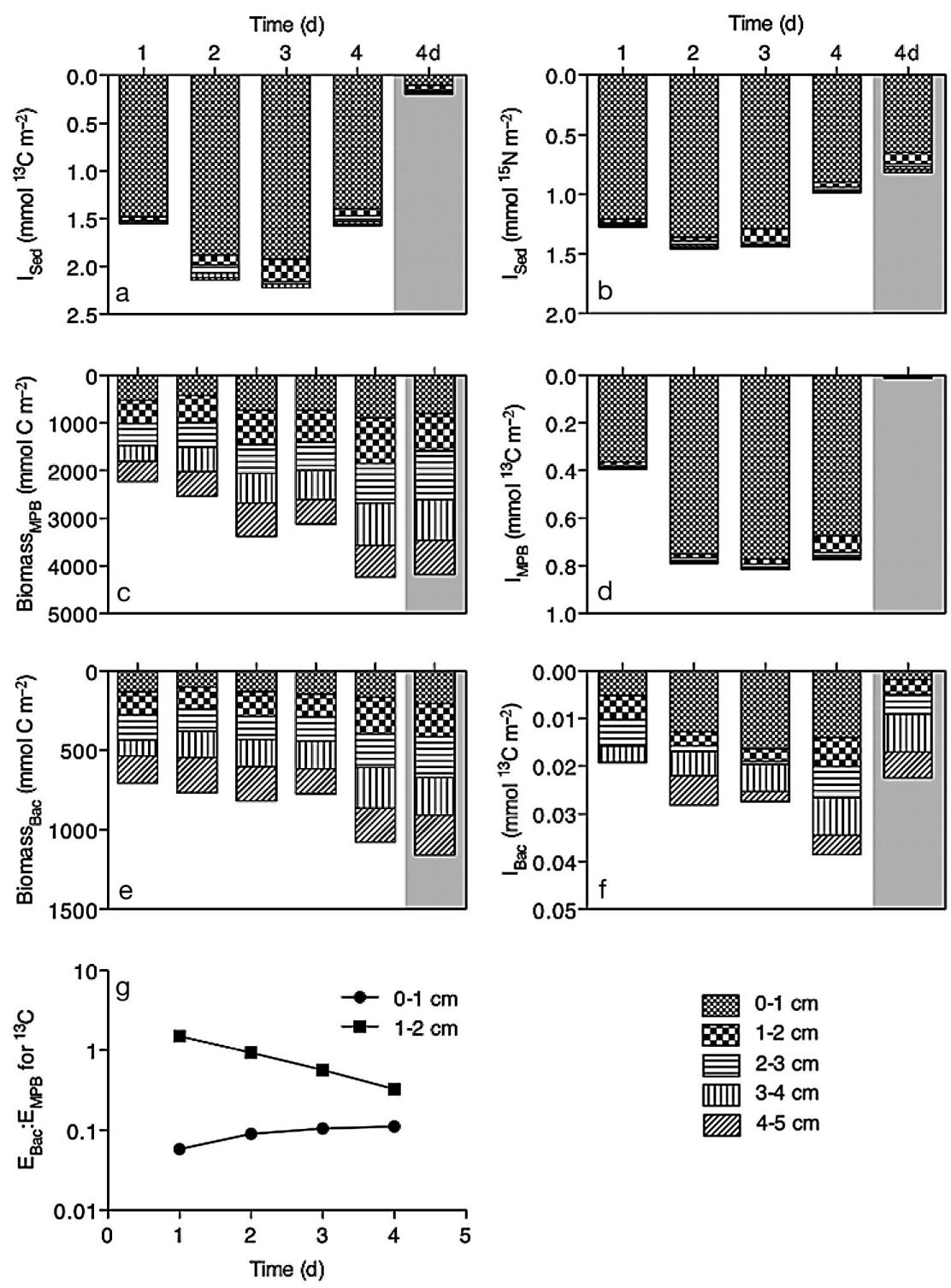

Fig. 4. (a) ${ }^{13} \mathrm{C}$ and (b) ${ }^{15} \mathrm{~N}$ incorporation (I) over time in bulk sediment for the different layers. MPB (c) biomass and (d) ${ }^{13} \mathrm{C}$ incorporation, and bacterial (e) biomass and (f) ${ }^{13} \mathrm{C}$ incorporation estimated from PLFA. (g) Bacteria to MPB ${ }^{13} \mathrm{C}$-atomic excess ratio over time in the $0-1$ and $1-2 \mathrm{~cm}$ sediment layers. Shaded area shows values for dark incubation on Day 4 (4d)

not vary significantly over time (data not shown). Maximum ${ }^{13} \mathrm{C}$ incorporation $\left(2.23 \mathrm{mmol}{ }^{13} \mathrm{C} \mathrm{m}^{-2}\right)$ integrated over the upper $5 \mathrm{~cm}$ of sediment was greater than that of ${ }^{15} \mathrm{~N}\left(1.46 \mathrm{mmol}^{15} \mathrm{~N} \mathrm{~m}^{-2}\right)$. On Day 1 , after 9 $\mathrm{h}$ of labelling, there was no incorporation below $4 \mathrm{~cm}$ and the total depth-integrated incorporation was $1.55 \mathrm{mmol}{ }^{13} \mathrm{C} \mathrm{m}^{-2}$. Considering that $10 \%$ of the DIC pool had been labelled and that all $\mathrm{C}$ remained in the sediment, i.e. respired ${ }^{13} \mathrm{C}$ measured in the DIC was negligible compared to the sediment incorporation (data not shown) and there was no resuspension, the total $\mathrm{C}$ fixed was $1.72 \mathrm{mmol} \mathrm{\textrm {m } ^ { - 2 }}$ $\mathrm{h}^{-1}$. This is in excellent agreement with the oxygen flux measurements (1.68 mmol m $\mathrm{m}^{-2} \mathrm{~h}^{-1}$ ) when considering a $\mathrm{C}$ fixation to oxygen production ratio of 1 (appropriate for a benthic community largely dominated by autotrophs) and confirms that $\mathrm{C}$ fixation was mostly caused by phototrophs with only a small contribution by chemoautotrophic bacteria. Thus, very little ${ }^{13} \mathrm{C}$ incorporation occurred in the dark $\left(0.19 \mathrm{mmol} \mathrm{m}{ }^{-2}\right)$. In contrast, total depth-integrated ${ }^{15} \mathrm{~N}$ incorporation in the dark was similar to that in the light $\left(0.82\right.$ and $0.99 \mathrm{mmol}{ }^{15} \mathrm{~N}$ $\mathrm{m}^{-2}$, respectively).

MPB biomass increased with time from $\sim 2230 \mathrm{mmol} \mathrm{C} \mathrm{m}^{-2}$ at the beginning of the experiment to $\sim 4240 \mathrm{mmol} \mathrm{C} \mathrm{m}^{-2}$ on Day 4 (Fig. 4c). MPB incorporation of ${ }^{13} \mathrm{C}$ based on PLFA ( $\mathrm{I}_{\mathrm{MPB}}$, Fig. 4d) was significant and rapid, particularly within the 0-1 cm layer, and stabilized at $\sim 0.8 \mathrm{mmol}^{13} \mathrm{C} \mathrm{m}^{-2}$ for the top $5 \mathrm{~cm}$ of sediment. Although most of the incorporation was restricted to the sediment surface, the deeper layers $(1-3 \mathrm{~cm})$ showed a slight increase with time, confirming burial of MPB as suggested earlier. ${ }^{13} \mathrm{C}$ incorporation into MPB in the light was $37 \pm 10 \%$ of total ${ }^{13} \mathrm{C}$ incorporation. MPB ${ }^{13} \mathrm{C}$ incorporation in the dark was small at $\sim 1.5 \%$ of that in the light. Bacterial biomass was smaller than that of MPB and also increased over the course of the experiment (Fig. 4e). Bacterial ${ }^{13} \mathrm{C}$ incorporation $\left(\mathrm{I}_{\mathrm{Bac}}\right.$ Fig. 4f) was small but significantly increased to a maximum of $0.04 \mathrm{mmol}^{13} \mathrm{C} \mathrm{m}^{-2}$ on Day 4 and showed dynamics distinct from that of the MPB. Some ${ }^{13} \mathrm{C}$ was incorporated by bacteria in the $0-1 \mathrm{~cm}$ layer, but most of the bacterial ${ }^{13} \mathrm{C}$ incorporation occurred in the deeper layers, beginning on Day 1. The fact that, from the first day onwards, most of the label incorporation was found in the deeper layer and in the same proportion as the incorporation during dark incubation suggests that there was a direct uptake of ${ }^{13} \mathrm{C}$-bicarbonate by the bacterial community. The difference of ${ }^{13} \mathrm{C}$ incorporation pathways of bacteria in the surface sediment and 
those inhabiting deeper layers was further supported by the data shown in Fig. $4 \mathrm{~g}$. In the same way as enrichment, atomic excess, E, revealed the label incorporation regardless of biomass (i.e. incorporation normalized by the biomass; $\mathrm{E}=\mathrm{I} / \mathrm{B}$ ) and the $\mathrm{E}_{\mathrm{Bac}}: \mathrm{E}_{\mathrm{MPB}}$ ratio for ${ }^{13} \mathrm{C}$ reflects the relative efficiencies of label uptake by bacteria and MPB. On Day 1, the ratio illustrated a higher labelling of MPB relative to bacteria at the surface, while the ratio for the $1-2 \mathrm{~cm}$ layer illustrated a higher labelling of bacteria relative to MPB. While the low and increasing ratio for the $0-1 \mathrm{~cm}$ layer from Day 1 on suggests a higher relative contribution of MPB ${ }^{13} \mathrm{C}$ and a subsequent transfer of ${ }^{13} \mathrm{C}$ to bacteria, a ratio greater than 1 on Day 1 and subsequently decreasing suggests an initial direct uptake of ${ }^{13} \mathrm{C}$ bicarbonate by bacteria, followed by a higher relative contribution of MPB ${ }^{13} \mathrm{C}$, possibly due to burial. This is consistent with increasing enrichment values for cyanobacterial PLFA as illustrated in Fig. 3d.
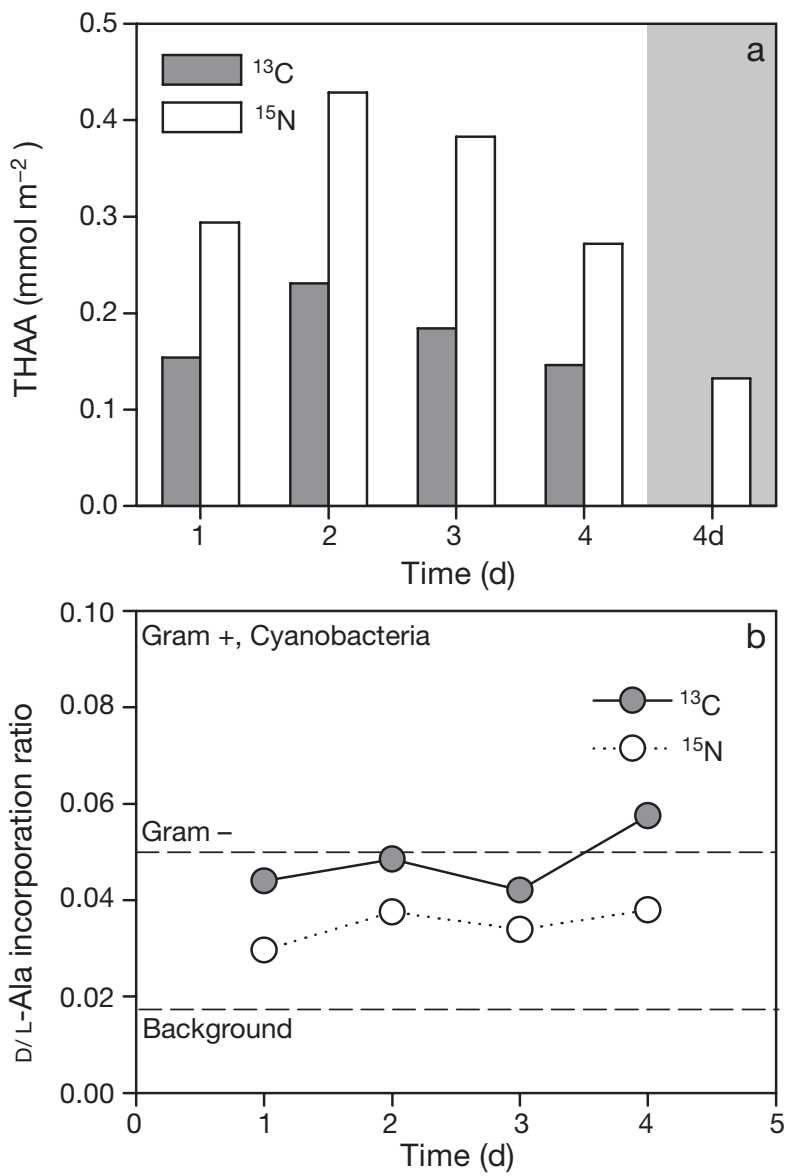

Fig. 5. (a) ${ }^{13} \mathrm{C}$ and ${ }^{15} \mathrm{~N}$ incorporation over time in total hydrolyzable amino acids (THAAs) in the $0-1 \mathrm{~cm}$ sediment layer. Shaded area shows values for dark incubation on Day 4 (4d). (b) D/L-Ala ratio of incorporation of ${ }^{13} \mathrm{C}$ and ${ }^{15} \mathrm{~N}$ in the $0-1 \mathrm{~cm}$ layer. D/L-Ala ratios for racemisation background (0.017), Gram-negative bacteria (0.05) and Gram-positive and cyanobacteria $(0.10)$ are indicated
Finally, ${ }^{13} \mathrm{C}$ and ${ }^{15} \mathrm{~N}$ incorporation into THAA was assessed for the $0-1 \mathrm{~cm}$ layer (Fig. 5a). ${ }^{13} \mathrm{C}$ and ${ }^{15} \mathrm{~N}$ incorporation into THAA followed similar dynamics, but was much lower than incorporation into the bulk sediment (Fig. 4a,b). Conversely to bulk sediment, ${ }^{15} \mathrm{~N}$ incorporation in THAA was higher than that of ${ }^{13} \mathrm{C}$. D/L-Ala incorporation ratios for ${ }^{13} \mathrm{C}$ and ${ }^{15} \mathrm{~N}$ were well above the racemisation background value of $\sim 0.017$ (representing D-Ala produced by racemisation during sample hydrolysis), implying a high contribution of bacteria to label incorporation (Fig. 5b).

\section{DISCUSSION}

The experiment presented here reveals pathways of $\mathrm{C}$ and $\mathrm{N}$ through the microbial communities of permeable marine sands in the photic zone. The use of stable $\mathrm{C}$ and $\mathrm{N}$ isotopes permitted quantification of the different microbial activities that lead to the incorporation of inorganic $\mathrm{C}$ and $\mathrm{N}$ into benthic biomass in these environments. The results show the dominance of photosynthetic $\mathrm{C}$ fixation and the independence of $\mathrm{N}$ assimilation from light conditions. The present study also highlights the role of EPS in the transfer of energy from MPB to the heterotrophic communities of photic subtidal sands.

Although the chambers used were suitable for in situ work, the experiment was conducted in the laboratory to (1) minimize potential losses of material, (2) prevent disturbance of the experimental settings by currents and waves and (3) facilitate periodic sampling. Extreme care was taken during sampling in the field to keep the sediment and its biogeochemical layering intact. The conditions of the laboratory experiment were designed to mimic the field conditions as closely as possible. The stirring in the chambers induced water percolation through the upper layers of the sediment as produced by bottom currents in the field. This percolation is critical for the natural metabolism in permeable subtidal sands because it dominates the solute exchange between the sediment and the overlying water column (Huettel et al. 1998, Huettel \& Rusch 2000). The experimental incubations simulated pore water exchange, as it is induced by tidal currents and waves in the field, although the intensity represented a conservative value with respect to those found under in situ conditions. Tidal currents and waves can cause higher pressure gradients at the study site than the $0.2 \mathrm{~Pa} \mathrm{~cm}^{-1}$ chosen for the experiment, and Cook \& Roy (2006) showed that enhanced pore water percolation can increase benthic photosynthesis in subtidal sands due to the advective relief of $\mathrm{CO}_{2}$ limitation in MPB. The light regime was similar to the average 
measured by Wenzhofer \& Glud (2004) under similar settings, and the water temperature was maintained close to in situ temperature. In contrast to intertidal areas, where similar labelling experiments can be carried out in situ and easily accessed for sampling on a daily basis (van Oevelen et al. 2006b, Veuger et al. 2006), subtidal permeable sediments need to be incubated in chambers allowing simulation of in situ flow conditions. The limited number of benthic chambers and associated hardware available as well as the work intensive and time consuming processing of the samples and associated high costs of the different analyses did not allow for extensive replication. Our approach is based on balancing replication with maximal resolution in the microbial compartments as well as simulating natural flow conditions. Although replication at a single time point might have allowed us to apply standard statistical analyses, we chose to follow a time-series approach because of the very low variance of the control $(<1 \%)$ and the high $\delta^{\mathrm{E}}$ values. Moreover, in the absence of prior information about the relevant time scales of microalgal and bacterial dynamics in permeable sediments, we believed that this pilot study would be most instructive if a timeseries approach was adopted. The systematic patterns observed from Days 1 to 4 provide some a posteriori confidence in our approach.

\section{Sediment microbial community}

Pigment analysis and PLFA data revealed that MPB biomass was homogeneously distributed at least within the top 2 and $5 \mathrm{~cm}$ of the sediment. These results support previous studies, which showed that large quantities of living MPB can be found as deep as $20 \mathrm{~cm}$ in sandy sediments (Steele \& Baird 1968, Jenness \& Duineveld 1985). In sandy sediments, living microalgae include not only BMA but also some phytoplankton (Steele \& Baird 1968). This could explain the presence of haptophytes in the sediment, which likely settled onto the sediment after a bloom prior to the experiment. Although diatoms dominated the MPB biomass $(\sim 60 \%)$, the sediment composition also revealed a large fraction of cyanobacteria, which represented $\sim 30 \%$ of MPB biomass. While one might argue the accuracy of the method used to obtain these estimates (i.e. CHEMTAX analysis instead of cell counts), cyanobacterial presence was confirmed by microscopic observations. The rather large proportion of cyanobacteria was consistent with previous studies that have reported abiotic factors like high temperatures and coarse sediment to be favourable conditions for cyanobacterial development (Watermann et al. 1999).
Based on the often used C:chl a ratio of 40 (de Jonge 1980), MPB biomass of the $0-1 \mathrm{~cm}$ layer would have been overestimated $\left(\sim 2600 \mathrm{mmol} \mathrm{C} \mathrm{m}^{-2}\right)$. More recent estimates based on a broader range of phytoplankton cultures suggest a ratio of 34 (N. A. Dijkman pers. comm.). This value was estimated from the same cultures used to estimate MPB PLFA concentrations (Dijkman \& Kromkamp 2006, N. A. Dijkman pers. comm.) and would imply a MPB biomass of about $2250 \mathrm{mmol} \mathrm{C}$ $\mathrm{m}^{-2}$, still well above the 1016 to $1849 \mathrm{mmol} \mathrm{C} \mathrm{m}^{-2}$ range estimated from PLFA from Day 0 to Day 4 for the top $2 \mathrm{~cm}$ of sediment. Both methods used to estimate MPB biomass are based on conversion factors derived from cultures of planktonic microalgae and cyanobacteria (Brinch-Iversen \& King 1990, Dijkman \& Kromkamp 2006, N. A. Dijkman pers. comm.) and perhaps are not representative of natural communities and benthic primary producers. These estimates for MPB in subtidal permeable sediments are high, but within the range of biomass found in sheltered silty intertidal areas (Sundback et al. 1991, Underwood \& Kromkamp 1999, Middelburg et al. 2000, Cook et al. 2004a). They are, however, significantly higher than estimates reported for subtidal sandy sediments (Sundback et al. 1991, Cahoon 1999).

\section{Algal production, EPS exudation and transfer to bacteria}

MPB production based on changes in oxygen concentration in light-dark incubations and on the ${ }^{13} \mathrm{C}$ incorporation in bulk sediment over the first day led to very similar results $\left(1.68\right.$ and $1.72 \mathrm{mmol} \mathrm{C} \mathrm{m}^{-2} \mathrm{~h}^{-1}$, respectively). MPB production in subtidal sediment was similar to that reported for sandy and silty intertidal sediments for the same period of the year (Barranguet et al. 1998). However, extrapolating to a daily production with $12 \mathrm{~h}$ daylight, MPB production $\left(\sim 20 \mathrm{mmol} \mathrm{C} \mathrm{m}^{-2} \mathrm{~d}^{-1}\right)$ was slightly lower than that measured in 2 shallow subtidal sediments investigated in the summer (Sundback et al. 1996) as well as that measured in situ at deeper sandy sediment sites on the South Atlantic Bight (Jahnke et al. 2000). Our results are also lower than the average value proposed by Cahoon (1999) from a compilation of data from various shallow subtidal locations, which showed extreme variability (bear in mind that those data were extrapolated to yearly production). Overall, the primary production $\left(\sim 20 \mathrm{mmol} \mathrm{C} \mathrm{m}{ }^{-2} \mathrm{~d}^{-1}\right)$ during our experiment was low despite a high biomass (1000 to $2250 \mathrm{mmol} \mathrm{C}$ $\mathrm{m}^{-2}$ based on chl a and PLFA, respectively), implying a relatively low turnover for MPB, i.e. high biomass to production ratios ( $\sim 50$ to 100$)$. These biomass to production ratios are at the higher end of reported values 
for sandy sediments ( 2 to 44 d; Sundback et al. 1996). This might suggest that growth conditions were not favourable at the time of the experiment and that the large standing stock of MPB is likely the result of significant previous blooms. Light was unlikely to have been limiting as the irradiance was set to that observed in the field at the sampling site and the experiment took place in the summer. Instead, nutrient conditions might have been limiting. This is supported by the significant fraction of primary production allocated to the exudation of EPS (see below). In addition, our data are consistent with those of Cook et al. (2007a), who showed that, in similar sediment under nutrientreplete conditions, primary production was at least twice as high.

Our data revealed some insights into the complex dynamics of the allocation of fixed C. While total C fixation was assessed by quantifying bulk sediment incorporation of ${ }^{13} \mathrm{C}$ (Fig. 4a), the part allocated to microbial biomass was estimated with 2 independent methods: via incorporation into PLFA (Fig. 4d,f) and THAA (Fig. 5a). Maximum enrichments were observed on Day 2; following this, ${ }^{13} \mathrm{C}$ incorporation into THAA accounted for $10 \%$ of bulk sediment incorporation and $28 \%$ of total microbial biomass incorporation estimated from PLFA. THAAs are considered to contribute $\sim 45 \%$ to microalgal biomass (Brown 1991, Cowie \& Hedges 1992) and $~ 50 \%$ to bacterial biomass (Simon \& Azam 1989, Cowie \& Hedges 1992). Therefore, we derived a ${ }^{13} \mathrm{C}_{\text {THAA }}:{ }^{13} \mathrm{C}_{\text {Biomass }}$ ratio of 0.46 (mol:mol) from the relative contributions of BMA (diatoms) and bacteria (both hetero- and autotrophic), allowing us to estimate microbial ${ }^{13} \mathrm{C}$ incorporation. In addition to the ${ }^{13} \mathrm{C}$ incorporation by the microbial compartment, a fraction of $\mathrm{C}$ fixation was very quickly transferred from primary producers to meiofauna and macrofauna (Evrard 2007). However, the faunal component can be neglected for the following interpretations because the maximum meiofauna ${ }^{13} \mathrm{C}$ assimilation represented $\sim 10 \mu \mathrm{mol} \mathrm{m}{ }^{-2}$ for the $0-1 \mathrm{~cm}$ sediment layer. Moreover, total respired ${ }^{13} \mathrm{C}$, estimated from measurements of ${ }^{13} \mathrm{C}$-DIC releases, was almost 2 orders of magnitude smaller than the ${ }^{13} \mathrm{C}$ assimilation in the meiofauna (Evrard 2007), and all macrofauna were handpicked and pulled out of the sediment samples before analysis and therefore were not part of the $\mathrm{C}$ content measured. Therefore, we estimate that on Day 2, 38\% (based on PLFA measurements) or $23 \%$ (based on THAA measurements) of the $\mathrm{C}$ was allocated to growth of microbial biomass. In other words, between 62 and $77 \%$ of the $\mathrm{C}$ fixed did not result in biomass formation, but was diverted to exudation of EPS. These results should be considered approximate given the dependence on conversion factors that are based on microbial cultures. Nevertheless, they unequivocally stress that, in our experiment, MPB allocated a major part of its production to the synthesis of EPS. Our findings confirm previous observations made in intertidal areas suggesting that 42 to $73 \%$ of $\mathrm{C}$ fixation can be excreted (Smith \& Underwood 1998, Goto et al. 1999, Middelburg et al. 2000, de Brouwer \& Stal 2001). Recently, Cook et al. (2007a), using similar permeable sediments in mesocosm experiments, reported that $50 \%$ of the fixed $\mathrm{C}$ was exuded in both nutrient-deplete as well as nutrient-replete conditions. In natural conditions, MPB exudation of EPS is significantly higher than that of phytoplankton (Goto et al. 1999) and can therefore provide a substantial substrate for benthic bacteria (Middelburg et al. 2000).

Heterotrophic bacteria living in sandy sediments are attached to sand grains and many of them grow close to active MPB (Huettel et al. 2003). While the response of heterotrophic bacteria on phytodetritus has been studied in permeable sediments (Sundback et al. 1996, Huettel et al. 2003, Buhring et al. 2006), little is known about the links between MPB and heterotrophic bacteria. In our experiment, MPB biomass was high, there was no apparent sign of MPB detritus (absence of phaeopigments), and about 62 to $77 \%$ of $\mathrm{C}$ fixation was directed to EPS. These conditions explain the immediate and continuous incorporation of ${ }^{13} \mathrm{C}$ into bacterial biomass at the sediment surface (Fig. 4f,g) and support the findings of previous studies which have demonstrated the strong affinity of bacteria for labile organic C from colloidal sources (Middelburg et al. 2000, Goto et al. 2001, van Oevelen et al. 2006a). However, the relatively low ${ }^{13} \mathrm{C}$ incorporation by bacteria, despite the large fraction of exuded EPS, hampers the determination of the actual total $\mathrm{C}$ assimilation. It is important to take into account the label dilution $(10 \%$ of the 'freshly' produced EPS) within the pool of EPS readily available to the heterotrophic bacteria. For example, on Day 2 at the maximum enrichment, assuming that EPS incorporation was $1.12 \mathrm{mmol}{ }^{13} \mathrm{C} \mathrm{m}^{-2}$ for the $0-1 \mathrm{~cm}$ layer (difference of incorporation between bulk sediment and microbial compartment estimated from PLFA), we derived a total EPS production of $11.2 \mathrm{mmol} \mathrm{C} \mathrm{m}^{-2}$ (DIC pool was $10 \%$ labelled). The EPS standing stock estimated from the difference between sediment organic $\mathrm{C}$ content $\left(2400 \mathrm{mmol} \mathrm{C} \mathrm{m}^{-2}\right.$ ), MPB and bacterial biomass (732 and $130 \mathrm{mmol} \mathrm{C} \mathrm{m}^{-2}$, respectively, estimated from PLFA) was $1538 \mathrm{mmol} \mathrm{C}$ $\mathrm{m}^{-2}$. Thus, the EPS ${ }^{13} \mathrm{C}$-labelled fraction was $1.12 /(1538$ $+11.2)=6.45 \times 10^{-4}$. Considering that bacterial ${ }^{13} \mathrm{C}$ incorporation on Day 2 was $0.013 \mathrm{mmol}^{13} \mathrm{C} \mathrm{m}^{-2}$ for the 0-1 cm layer, and assuming that bacteria relied exclusively on EPS as their substrate, we obtain a bacterial secondary production of $0.013 / 6.4510^{-4}=20.1 \mathrm{mmol} \mathrm{C}$ $\mathrm{m}^{-2} \mathrm{~d}^{-1}$. Although this bacterial secondary production estimate should be considered approximate at best, it 
clearly highlights the high bacterial activity taking place in permeable sediments. Based on a bacterial biomass of $130 \mathrm{mmol} \mathrm{C} \mathrm{m}^{-2}$ (estimated from PLFA) and the secondary production, we derive a turnover of $\sim 0.15 \mathrm{~d}^{-1}$, which is twice that found on an exposed sandy beach (Koop \& Griffiths 1982), and within the range reported for muddy and sandy coastal sands in the Mediterranean (Luna et al. 2002). Similar calculations for Day 1 yield significantly lower turnover rates, perhaps reflecting a delay related to the activation of 'dormant' bacteria (Luna et al. 2002). Contrary to the bacteria to MPB ${ }^{13} \mathrm{C}$-atomic excess ratio observed at the sediment surface (Fig. 4g), the deeper layer showed an opposite trend suggesting a different ${ }^{13} \mathrm{C}$ incorporation pathway.

\section{Chemoautotrophy}

The dark incubation showed significant incorporation of ${ }^{13} \mathrm{C}$ with higher incorporation into the deeper layer (Fig. 4a), although this was relatively low compared to that found in the light incubations. Because no photosynthesis took place in the dark core, incorporation could either be fuelled by an exogenous source of labelled organic matter (contamination of the dark cores by labelled substrate originating from cores in the light) or from direct incorporation of inorganic ${ }^{13} \mathrm{C}$ into the microbial compartment by anapleurotic $\mathrm{C}$ fixation or chemoautotrophy. Transfer of labelled DOC within cores due to resuspension was negligible as demonstrated by Cook et al. (2007a). Anapleurotic C fixation might have occurred, but cannot explain the incorporation of ${ }^{13} \mathrm{C}$ in PLFA in the dark (Boschker \& Middelburg 2002), indicating that chemoautotrophy was involved.

This is supported by immediate bulk sediment incorporation of ${ }^{13} \mathrm{C}$ in the deeper layers well below the photic zone, which we could not attribute to ${ }^{13} \mathrm{C}$ assimilation from buried ${ }^{13} \mathrm{C}$-labelled EPS, but could attribute to direct ${ }^{13} \mathrm{C}$-DIC fixation through chemoautotrophy. This is supported by the PLFA data showing that most dark and subsurface ${ }^{13} \mathrm{C}$ enrichment occurred in bacterial-specific biomarkers (Fig. 3d). Although EPS may be transported into deeper layers and metabolized by bacteria very quickly, it is unlikely that burial alone would be responsible for all the incorporation in the deeper layers. Chemoautotrophic $\mathrm{C}$ fixation is also consistent with the incorporation profile, showing more bacterial ${ }^{13} \mathrm{C}$ in the deeper layers $(1-5 \mathrm{~cm})$ than at the sediment surface (Fig. 4f), and also by the opposite trend of the bacteria to $\mathrm{MPB}{ }^{13} \mathrm{C}$ atomic excess ratio for the $0-1$ and $1-2 \mathrm{~cm}$ layers (Fig. 4g). Little is known about chemoautotrophy in permeable sediments and its co-occurrence with het- erotrophic bacterial activity, but the importance of the coupling between chemoautotrophy and heterotrophy has previously been shown for muddy sediments (Kepkay \& Novitsky 1980). Nevertheless, chemoautotrophy remained relatively low compared to bacterial heterotrophy $(\sim 1 \%$ if we consider that chemoautotrophic bacteria were $10 \%$ labelled, as was their substrate). Our findings support previous evidence of the contribution of chemoautotrophy to $\mathrm{C}$ fixation in subsurface sandy sediments (Thomsen \& Kristensen 1997). Parallel experiments at the study site also showed a large $\mathrm{HCl}$-extractable $\mathrm{Fe}^{2+}$ pool (presumably associated with reduced sulphides), which was rapidly re-oxidised when the sediments were exposed to oxygen, supporting the hypothesised presence of an active chemoautotrophic community (Cook et al. 2007b).

\section{C fixation vs. $\mathrm{N}$ assimilation}

Although the bulk sediment showed similar patterns of ${ }^{13} \mathrm{C}$ and ${ }^{15} \mathrm{~N}$ incorporation both in dynamics and amplitude, one has to consider the labelled fraction in each pool. The DIC pool was $10 \%{ }^{13} \mathrm{C}$-labelled, while the $\mathrm{N}$ pool was $\sim 95 \%$ labelled because there was almost no dissolved $\mathrm{N}$ in the overlying water and pore water DIN of the first $5 \mathrm{~cm}$ of sediment was negligible compared to the quantity added (Hedtkamp 2005). The measurements of bulk sediment $\mathrm{C}$ and $\mathrm{N}$ incorporation revealed that the average $\mathrm{C}: \mathrm{N}$ ratio of assimilation was 12.6, which is much larger than expected for microbial growth and hints at a large EPS production. If we attribute all $\mathrm{N}$ assimilation to MPB biomass (i.e. assuming that EPS does not contain N), and combine this with $\mathrm{C}$ fixation from the PLFA data (MPB C biomass), the $\mathrm{C}: \mathrm{N}$ ratio of assimilation varied from 5.4 to 6.8 , values close to the Redfield ratio. Similar to the ${ }^{13} \mathrm{C}$ incorporation into THAA, ${ }^{15} \mathrm{~N}$ incorporation into THAA was less than that of the bulk sediment incorporation but represented a higher relative contribution of $32 \pm 4 \%$. The difference between ${ }^{13} \mathrm{C}$ and ${ }^{15} \mathrm{~N}$ incorporation in THAA relative to the incorporation in bulk sediments is consistent with the fact that $\mathrm{N}_{\text {THAA }}: \mathrm{N}_{\text {Biomass }}$ is higher than $\mathrm{C}_{\mathrm{THAA}}$ : $\mathrm{C}_{\text {Biomass }}$ (Cowie \& Hedges 1992). Finally, the assimilation $\mathrm{C}: \mathrm{N}$ ratio based on the THAA did not vary and had an average value of 5.2. Both the PLFA and THAA based approaches are consistent with Redfield ratios for microbial growth and significant allocation of fixed $\mathrm{C}$ to EPS.

The most remarkable difference observed between $\mathrm{C}$ and $\mathrm{N}$ fixation was the incorporation in the dark incubation. While ${ }^{13} \mathrm{C}$ fixation in the dark was predominantly limited to chemoautotrophy, total ${ }^{15} \mathrm{~N}$ fixation in the dark was $\sim 90 \%$ of the light-dark incubation on Day 4. Diurnal variations in $\mathrm{C}$ and $\mathrm{N}$ assimilation by 
planktonic communities have been the subject of numerous studies (Berges et al. 1995, Clark et al. 2002, Needoba \& Harrison 2004, Holl \& Montoya 2005). Phytoplankton fixes $\mathrm{C}$ during light exposure, but can assimilate nitrate in the light as well as in the dark (Dugdale \& Goering 1967). To our knowledge, dark assimilation of nitrate by MPB has only been suggested in the literature a few times (Sundback \& Snoeijs 1991, Rysgaard et al. 1993, Cook et al. 2004b). Bacteria (with low $\mathrm{C}: \mathrm{N}$ ratio) can also assimilate inorganic $\mathrm{N}$ to balance the high C:N ratio of their substrate (Goldman \& Dennett 2000). Given that heterotrophic bacteria in subtidal permeable sediments rely primarily on EPS, one might expect significant bacterial $\mathrm{N}$ uptake (Kirchman \& Wheeler 1998, Allen et al. 2001, Van den Meersche et al. 2004). The present study is the first to report such a high assimilation of nitrate in the dark through assessing the actual ${ }^{15} \mathrm{~N}$ incorporation into biomass via THAA rather than bulk sediment. Future research might determine the relative contribution of diatoms and cyanobacteria to nitrate assimilation and unravel whether incorporation occurs directly as nitrate or as ammonium following dissimilatory nitrate reduction.

\section{${ }^{13} \mathrm{C}$ and ${ }^{15} \mathrm{~N}$ incorporation in D-Ala}

While THAA is informative of the biomass of all living organisms in the sediment, D-Ala provides a tool to assess the significance of bacteria. D-Ala, contrary to L-Ala, which is found in all living organisms, is only present in the biomass of prokaryotes (primarily peptidoglycan). Therefore, incorporation of ${ }^{13} \mathrm{C}$ and ${ }^{15} \mathrm{~N}$ into D-Ala can be attributed to assimilation by heterotrophic bacteria (Hbac), chemoautotrophic bacteria (Cbac) or cyanobacteria. D-Ala is the only biomarker which allows researchers to trace the fate of $\mathrm{N}$ through all microbial compartments.

The ${ }^{13} \mathrm{C}$ and ${ }^{15} \mathrm{~N}$ D/L-Ala incorporation ratios (Fig. 5b) provide a direct indication of the contribution of prokaryotes/bacteria (i.e. Hbac, Cbac and cyanobacteria) to total microbial (i.e. prokaryotes/bacteria + BMA) ${ }^{13} \mathrm{C}$ and ${ }^{15} \mathrm{~N}$ incorporation. For ${ }^{13} \mathrm{C}$, the low incorporation into PLFA $\mathrm{Bac}_{\text {-sp }}$ indicates that ${ }^{13} \mathrm{C}$ incorporation into microbial biomass was dominated by MPB. Therefore, the measured ${ }^{13} \mathrm{C}$ D/L-Ala ratios of incorporation are consistent with the uptake of ${ }^{13} \mathrm{C}$ by BMA $(\sim 0.017$, around racemisation background, as BMA do not contain D-Ala) and cyanobacteria ( 0.1) (Veuger et al. 2005). The average ${ }^{13} \mathrm{C} \mathrm{D} / \mathrm{L}-\mathrm{Ala}$ ratio of incorporation of 0.046 indicates that cyanobacteria contributed $\sim 35 \%$ of the total ${ }^{13} \mathrm{C}$ incorporation, leaving a $\sim 65 \%$ contribution for BMA. These contributions are in excellent agreement with their relative biomass based on pigment analyses (Fig. 2).
Interpretation of the ${ }^{15} \mathrm{~N}$ D/L-Ala ratios of incorporation is less straightforward, as these values may also include a significant contribution by Hbac and/or Cbac (D/L-Ala ratios between 0.05 and 0.1) (Veuger et al. 2005). Therefore, we can only derive an estimate of the prokaryotic (cyanobacteria + Hbac + Cbac) contribution to total ${ }^{15} \mathrm{~N}$ incorporation (prokaryotes + BMA), which was 23 to $58 \%$.

The present study illustrates some of the complex interactions within the microbial compartments in shallow, subtidal, sandy sediment in the photic zone. Our experiment was limited to a $4 \mathrm{~d}$ period and based on limited replication; thus, it requires follow-up before definite conclusions can be drawn. However, the combined isotope-biomarker approach clearly revealed that the majority of the $\mathrm{C}$ fixed by MPB (diatoms and cyanobacteria) was diverted to the production of EPS, and this EPS in turn served as a substrate for heterotrophic bacteria.

Acknowledgements. This research was supported by the European Union (COSA project, EVK\#3-CT-2002-00076) and the Netherlands Organisation for Scientific Research (PIONIER 833.02.002). M. Houtekamer, P. van Breugel and P. van Rijswijk are warmly thanked for analytical support. We are grateful to N. A. Dijkman for her precious help with the analysis of the pigment data and to 4 anonymous reviewers and editor R. de Wit for their patience and constructive feedbacks that helped improve the manuscript. This is NIOO-KNAW publication no. 4392 .

\section{LITERATURE CITED}

Allen AE, Booth MG, Frischer ME, Verity PG, Zehr JP, Zani S (2001) Diversity and detection of nitrate assimilation genes in marine bacteria. Appl Environ Microbiol 67:5343-5348

Barranguet C, Kromkamp J, Peene J (1998) Factors controlling primary production and photosynthetic characteristics of intertidal microphytobenthos. Mar Ecol Prog Ser 173:117-126

Berges JA, Cochlan WP, Harrison PJ (1995) Laboratory and field responses of algal nitrate reductase to diel periodicity in irradiance, nitrate exhaustion, and the presence of ammonium. Mar Ecol Prog Ser 124:259-269

Boschker HTS, Middelburg JJ (2002) Stable isotopes and biomarkers in microbial ecology. FEMS Microbiol Ecol 40:85-95

Boschker HTS, de Brouwer JFC, Cappenberg TE (1999) The contribution of macrophyte-derived organic matter to microbial biomass in salt-marsh sediments: stable carbon isotope analysis of microbial biomarkers. Limnol Oceanogr 44:309-319

Boschker HTS, Kromkamp JC, Middelburg JJ (2005) Biomarker and carbon isotopic constraints on bacterial and algal community structure and functioning in a turbid, tidal estuary. Limnol Oceanogr 50:70-80

Boudreau BP, Huettel M, Forster S, Jahnke RA and others (2001) Permeable marine sediments: overturning an old paradigm. EOS Trans Am Geophys Union 82:133-136

Brinch-Iversen J, King GM (1990) Effects of substrate concentration, growth state, and oxygen availability on relation- 
ships among bacterial carbon, nitrogen and phospholipid phosphorus content. FEMS Microbiol Ecol 74:345-355

Brown MR (1991) The amino-acid and sugar composition of 16 species of microalgae used in mariculture. J Exp Mar Biol Ecol 145:79-99

Buhring SI, Ehrenhauss S, Kamp A, Moodley L, Witte U (2006) Enhanced benthic activity in sandy sublittoral sediments: evidence from C-13 tracer experiments. Mar Biol Res 2: $120-129$

Cahoon LB (1999) The role of benthic microalgae in neritic ecosystems. Oceanogr Mar Biol Annu Rev 37:47-86

> Clark DR, Flynn KJ, Owens NJP (2002) The large capacity for dark nitrate-assimilation in diatoms may overcome nitrate limitation of growth. New Phytol 155:101-108

Cook PLM, Roy $\mathrm{H}$ (2006) Advective relief of $\mathrm{CO}_{2}$ limitation in microphytobenthos in highly productive sandy sediments. Limnol Oceanogr 51:1594-1601

Cook PLM, Butler ECV, Eyre BD (2004a) Carbon and nitrogen cycling on intertidal mudflats of a temperate Australian estuary. I. Benthic metabolism. Mar Ecol Prog Ser 280: 25-38

Cook PLM, Revill AT, Butler ECV, Eyre BD (2004b) Carbon and nitrogen cycling on intertidal mudflats of a temperate Australian estuary. II. Nitrogen cycling. Mar Ecol Prog Ser 280:39-54

Cook PLM, Veuger B, Böer S, Middelburg JJ (2007a) Effect of nutrient availability on carbon and nitrogen incorporation and flows through benthic algae and bacteria in nearshore sandy sediment. Aquat Microb Ecol 49:165-180

Cook PLM, Wenzhofer F, Glud RN, Janssen F, Huettel M (2007b) Benthic solute exchange and carbon mineralization in two shallow subtidal sandy sediments: effect of advective pore-water exchange. Limnol Oceanogr 52: 1943-1963

Cowie GL, Hedges JI (1992) Sources and reactivities of amino acids in a coastal marine environment. Limnol Oceanogr 37:703-724

> Dauwe B, Middelburg JJ, Herman PMJ (2001) Effect of oxygen on the degradability of organic matter in subtidal and intertidal sediments of the North Sea area. Mar Ecol Prog Ser 215:13-22

de Beer D, Wenzhofer F, Ferdelman TG, Boehme SE and others (2005) Transport and mineralization rates in North Sea sandy intertidal sediments, Sylt-Romo Basin, Wadden Sea. Limnol Oceanogr 50:113-127

de Brouwer JFC, Stal LJ (2001) Short-term dynamics in microphytobenthos distribution and associated extracellular carbohydrates in surface sediments of an intertidal mudflat. Mar Ecol Prog Ser 218:33-44

de Jonge VN (1980) Fluctuations in the organic carbon to chlorophyll a ratios for estuarine benthic diatom populations. Mar Ecol Prog Ser 2:345-353

Dijkman NA, Kromkamp JC (2006) Phospholipid-derived fatty acids as chemotaxonomic markers for phytoplankton: application for inferring phytoplankton composition. Mar Ecol Prog Ser 324:113-125

Dugdale RC, Goering JJ (1967) Uptake of new and regenerated forms of nitrogen in primary productivity. Limnol Oceanogr 12:196-206

Ehrenhauss S, Witte U, Bühring SI, Huettel M (2004) Effect of advective pore water transport on distribution and degradation of diatoms in permeable North Sea sediments. Mar Ecol Prog Ser 271:99-111

Emery KO (1968) Relict sediments on continental shelves of world. AAPG Bull 52:445-464

Evrard V (2007) Assessing the fate of organic matter in subtidal sandy sediments using carbon and nitrogen stable isotopes as deliberate tracers. PhD thesis, Utrecht University, Utrecht. Available at http://igitur-archive. library.uu.nl/dissertations/2007-0830-080158/index.htm

Franke U, Polerecky L, Precht E, Huettel M (2006) Wave tank study of particulate organic matter degradation in permeable sediments. Limnol Oceanogr 51:1084-1096

Gattuso JP, Gentili B, Duarte CM, Kleypas JA, Middelburg JJ, Antoine D (2006) Light availability in the coastal ocean: impact on the distribution of benthic photosynthetic organisms and their contribution to primary production. Biogeosciences 3:489-513

Goldman JC, Dennett MR (2000) Growth of marine bacteria in batch and continuous culture under carbon and nitrogen limitation. Limnol Oceanogr 45:789-800

Goto N, Kawamura T, Mitamura O, Terai H (1999) Importance of extracellular organic carbon production in the total primary production by tidal-flat diatoms in comparison to phytoplankton. Mar Ecol Prog Ser 190:289-295

Goto N, Mitamura O, Terai H (2001) Biodegradation of photosynthetically produced extracellular organic carbon from intertidal benthic algae. J Exp Mar Biol Ecol 257: $73-86$

Grasshoff K, Kremling K, Ehrhardt M (1999) Methods of seawater analysis, 3rd edn. Wiley-VCH, Weinheim

Hedtkamp S (2005) Shallow subtidal sand: permeability, nutrient dynamics, microphytobenthos and organic matter. Christian-Albrechts-Universität, Kiel

Holl CM, Montoya JP (2005) Interactions between nitrate uptake and nitrogen fixation in continuous cultures of the marine diazotroph Trichodesmium (Cyanobacteria). J Phycol 41:1178-1183

> Huettel M, Gust G (1992a) Impact of bioroughness on interfacial solute exchange in permeable sediments. Mar Ecol Prog Ser 89:253-267

Huettel M, Gust G (1992b) Solute release mechanisms from confined sediment cores in stirred benthic chambers and flume flows. Mar Ecol Prog Ser 82:187-197

Huettel M, Rusch A (2000) Transport and degradation of phytoplankton in permeable sediment. Limnol Oceanogr 45:534-549

Huettel M, Ziebis W, Forster S (1996) Flow-induced uptake of particulate matter in permeable sediments. Limnol Oceanogr 41:309-322

Huettel M, Ziebis W, Forster S, Luther GW (1998) Advective transport affecting metal and nutrient distributions and interfacial fluxes in permeable sediments. Geochim Cosmochim Acta 62:613-631

> Huettel M, Roy H, Precht E, Ehrenhauss S (2003) Hydrodynamical impact on biogeochemical processes in aquatic sediments. Hydrobiologia 494:231-236

Jahnke RA, Nelson JR, Marinelli RL, Eckman JE (2000) Benthic flux of biogenic elements on the Southeastern US continental shelf: influence of pore water advective transport and benthic microalgae. Cont Shelf Res 20:109-127

Janssen F, Faerber P, Huettel M, Meyer V, Witte U (2005a) Pore-water advection and solute fluxes in permeable marine sediments (I): calibration and performance of the novel benthic chamber system SANDY. Limnol Oceanogr 50:768-778

Janssen F, Huettel M, Witte U (2005b) Pore-water advection and solute fluxes in permeable marine sediments (II): benthic respiration at three sandy sites with different permeabilities (German Bight, North Sea). Limnol Oceanogr 50: 779-792

Jenness MI, Duineveld GCA (1985) Effects of tidal currents on chlorophyll a content of sandy sediments in the southern North Sea. Mar Ecol Prog Ser 21:283-287 
Kepkay PE, Novitsky JA (1980) Microbial control of organic carbon in marine sediments: coupled chemoautotrophy and heterotrophy. Mar Biol 55:261-266

Kirchman DL, Wheeler PA (1998) Uptake of ammonium and nitrate by heterotrophic bacteria and phytoplankton in the sub-Arctic Pacific. Deep-Sea Res I 45:347-365

Koop K, Griffiths CL (1982) The relative significance of bacteria, meiofauna and macrofauna on an exposed sandy beach. Mar Biol 66:295-300

Kristensen E, Hansen K (1995) Decay of plant detritus in organic-poor marine sediment: production rates and stoichiometry of dissolved C and N compounds. J Mar Res 53:675-702

Luna GM, Manini E, Danovaro R (2002) Large fraction of dead and inactive bacteria in coastal marine sediments: comparison of protocols for determination and ecological significance. Appl Environ Microbiol 68:3509-3513

MacIntyre HL, Geider RJ, Miller DC (1996) Microphytobenthos: the ecological role of the 'secret garden' of unvegetated, shallow-water marine habitats. I. Distribution, abundance and primary production. Estuaries 19:186-201

Mackey MD, Mackey DJ, Higgins HW, Wright SW (1996) CHEMTAX?a program for estimating class abundances from chemical markers: application to HPLC measurements of phytoplankton. Mar Ecol Prog Ser 144:265-283

Maddi P, Carman KR, Fry B, Wissel B (2006) Use of primary production by harpacticoid copepods in a Louisiana saltmarsh food web. In: Kromkamp JC, de Brouwer JFC, Blanchard GF, Forster RM, Créach V (eds) Functioning of microphytobenthos in estuaries. Royal Netherlands Academy of Arts and Sciences, Amsterdam, p 65-81

Middelburg JJ, Barranguet C, Boschker HTS, Herman PMJ, Moens T, Heip CHR (2000) The fate of intertidal microphytobenthos carbon: an in situ ${ }^{13} \mathrm{C}$-labeling study. Limnol Oceanogr 45:1224-1234

Moodley L, Boschker HTS, Middelburg JJ, Pel R, Herman PMJ, de Deckere E, Heip CHR (2000) Ecological significance of benthic foraminifera: ${ }^{13} \mathrm{C}$ labelling experiments. Mar Ecol Prog Ser 202:289-295

Needoba JA, Harrison PJ (2004) Influence of low light and a light:dark cycle on $\mathrm{NO}_{3}{ }^{-}$uptake, intracellular $\mathrm{NO}_{3}{ }^{-}$, and nitrogen isotope fractionation by marine phytoplankton. J Phycol 40:505-516

Precht E, Huettel M (2003) Advective pore-water exchange driven by surface gravity waves and its ecological implications. Limnol Oceanogr 48:1674-1684

Riedl RJ, Machan R, Huang N (1972) Subtidal pump: mechanism of interstitial water exchange by wave action. Mar Biol 13:210-221

Rusch A, Huettel M (2000) Advective particle transport into permeable sediments: evidence from experiments in an intertidal sandflat. Limnol Oceanogr 45:525-533

Rusch A, Forster S, Huettel M (2001) Bacteria, diatoms and detritus in an intertidal sandflat subject to advective transport across the water-sediment interface. Biogeochemistry 55:1-27

Rysgaard S, Risgaard-Petersen N, Nielsen LP, Revsbech NP (1993) Nitrification and denitrification in lake and estuarine sediments measured by the ${ }^{15} \mathrm{~N}$ dilution technique and isotope pairing. Appl Environ Microbiol 59:2093-2098

Editorial responsibility: Rutger de Wit, Montpellier, France
Shum KT, Sundby B (1996) Organic matter processing in continental shelf sediments: the subtidal pump revisited. Mar Chem 53:81-87

Simon M, Azam F (1989) Protein content and protein synthesis rates of planktonic marine bacteria. Mar Ecol Prog Ser 51:201-213

Smith DJ, Underwood GJC (1998) Exopolymer production by intertidal epipelic diatoms. Limnol Oceanogr 43: 1578-1591

Steele JH, Baird IE (1968) Production ecology of a sandy beach. Limnol Oceanogr 13:14-25

Sundback K, Snoeijs P (1991) Effects of nutrient enrichment on microalgal community composition in a coastal shallow-water sediment system: an experimental study. Bot Mar 34:341-358

Sundback K, Enoksson V, Graneli W, Pettersson K (1991) Influence of sublittoral microphytobenthos on the oxygen and nutrient flux between sediment and water: a laboratory continuous-flow study. Mar Ecol Prog Ser 74:263-279

> Sundback K, Nilsson P, Nilsson C, Jonsson B (1996) Balance between autotrophic and heterotrophic components and processes in microbenthic communities of sandy sediments: a field study. Estuar Coast Shelf Sci 43:689-706

Thomsen U, Kristensen E (1997) Dynamics of sigma $\mathrm{CO}_{2}$ in a surficial sandy marine sediment: the role of chemoautotrophy. Aquat Microb Ecol 12:165-176

Underwood GJC, Kromkamp J (1999) Primary production by phytoplankton and microphytobenthos in estuaries. In: Advances in ecological research, Vol 29. Academic Press, San Diego, CA, p 93-153

Van den Meersche K, Middelburg JJ, Soetaert K, van Rijswijk P, Boschker HTS, Heip CHR (2004) Carbon-nitrogen coupling and algal-bacterial interactions during an experimental bloom: modeling a ${ }^{13} \mathrm{C}$ tracer experiment. Limnol Oceanogr 49:862-878

van Oevelen D, Middelburg JJ, Soetaert K, Moodley L (2006a) The fate of bacterial carbon in an intertidal sediment: modeling an in situ isotope tracer experiment. Limnol Oceanogr 51:1302-1314

van Oevelen D, Moodley L, Soetaert K, Middelburg JJ (2006b) The trophic significance of bacterial carbon in a marine intertidal sediment: results of an in situ stable isotope labeling study. Limnol Oceanogr 51:2349-2359

Veuger B, Middelburg JJ, Boschker HTS, Houtekamer M (2005) Analysis of ${ }^{15} \mathrm{~N}$ incorporation into D-alanine: a new method for tracing nitrogen uptake by bacteria. Limnol Oceanogr Methods 3:230-240

Veuger B, van Oevelen D, Boschker HTS, Middelburg JJ (2006) Fate of peptidoglycan in an intertidal sediment: an in situ ${ }^{13} \mathrm{C}$-labeling study. Limnol Oceanogr 51:1572-1580

Watermann F, Hillebrand H, Gerdes G, Krumbein WE, Sommer U (1999) Competition between benthic cyanobacteria and diatoms as influenced by different grain sizes and temperatures. Mar Ecol Prog Ser 187:77-87

Wenzhofer F, Glud RN (2004) Small-scale spatial and temporal variability in coastal benthic $\mathrm{O}_{2}$ dynamics: effects of fauna activity. Limnol Oceanogr 49:1471-1481

Wieland A, Paper T, Mobius J, Klock JH, Michaelis W (2008) Carbon pools and isotopic trends in hypersaline cyanobacterial mat. Geobiology 6:171-186

Submitted: March 12, 2007; Accepted: September 10, 2008

Proofs received from author(s): November 21, 2008 